\title{
Spirituality, dual career family worker, demographic factors, and organizational commitment: evidence from religious affairs in Indonesia
}

\author{
Abdul Aziz Nugraha Pratama \\ Faculty of Economics and Islamic Business IAIN Salatiga \\ E-mail:pratama_abdul@yahoo.com \\ DOI: $10.18326 /$ ijims.v7i2.277-304
}

Tulus Haryono, Salamah Wahyuni, Asri Laksmi Riani

Faculty of Economics and Business, Universitas Sebelas Maret

Hikmah Endraswati

Faculty of Economics and Islamic Business IAIN Salatiga

E-mail:h_endraswati@yahoo.co.id

\begin{abstract}
The purpose of this study is to specify whether spirituality, age, and tenure have an effect on organizational commitment and to determine whether the moderating variables, i.e. dual career family worker, moderates the effect of spirituality, age, and tenure on organizational commitment. The samples of the study were 90 staffs and lecturers of three educational institutions under
\end{abstract}


the Ministry of Religious Affairs located in Central Java. They were IAIN Surakarta, IAIN Salatiga, and MTsN 1 Surakarta. The research used Moderated Regression Analysis to analyze the data. The results showed that spirituality and tenure positively affect organizational commitment and dual career family worker moderated the effect of spirituality and tenure on organizational commitment. Dual career family worker in this study can be categorized as a quasi-moderation variable.

Tujuan dari penelitian ini adalah untuk mengetahui apakah spiritualitas, usia, dan masa jabatan berpengaruh terhadap komitmen organisasi dan untuk menentukan apakah dual career family worker sebagai variabel moderasi dapat memoderasi pengaruh spiritualitas, usia, dan masa jabatan terhadap komitmen organisasi. Penelitian ini menggunakan 90 karyawan dan dosen sebagai sampel dari tiga institusi pendidikan di bawah Kementerian Agama di Jawa Tengah: IAIN Surakarta, IAIN Salatiga, dan MTsN 1 Surakarta. Teknik analisis yang digunakan dalam penelitian ini adalah Analisis Regresi Moderasi. Hasilnya menunjukkan bahwa spiritualitas dan masa jabatan secara positif mempengaruhi komitmen organisasi dan dual career family worker sebagai variabel moderasi mampu memoderasi spiritualitas dan masa jabatan terhadap komitmen organisasi. Dual career family worker dalam penelitian ini dimasukkan sebagai variabel moderasi kuasi.

Keywords: Spirituality; Age; Tenure; Dual-career family worker; Organizational commitment

\section{Introduction}

Establishing a code of ethics and work culture is one of the steps taken by the Ministry of Religious Affairs in improving governance at the ministry. There are three values that should be considered in order to implement the work culture: integrity, professionalism, and work to achieve a common goal and togetherness in work. Integrity is the persistence of attitudes in maintaining ethical principles and professionalism, keeping the loyalty in the implementation of the task, and having a responsibility based on 
honesty. Values of integrity include the issues of ethics and spirituality, promoting exemplary value, and honesty. Therefore integrity is the most fundamental component and it will affect the overall individual and group behavior in carrying out any duties and responsibility entrusted to him. ${ }^{1}$

Indonesian Government Regulation No. 46 of 2011 regarding the Assessment of Civil Servants Job Performance Article 12 Paragraph (1) states that The ratings of behavior as referred in Article 4 letter b includes several aspects such as service orientation, integrity, commitment, discipline, cooperation, and leadership. In the explanation of the law, Article 12 Paragraph (1) letter c stated that "commitment" is civil servants willingness and ability to align their attitudes and actions to achieve organizational objectives by focusing on the service rather than self-interest, a person, and /or class.

The term commitment in the regulation, in the literature of Management $^{2}$ is well known with Organizational Commitment. Organizational Commitment is the psychological contract between employee and or organization that makes it less likely for employees to voluntarily leave the organization. ${ }^{3}$

The statement above is relevant to the statement from the Minister of Religious Affairs. According to the Minister of Religious Affairs, The Five Work Culture in Ministry of Religious Affairs include integrity, professionalism, innovation, responsibility, and exemplary. ${ }^{4}$ These values are needed in improving the existing bureaucracy in Indonesia such

\footnotetext{
${ }^{1}$ Mukodas Arif Subekti, "Strategi Kemenag dalam Memperteguh Komitmen Menjadikan Kementerian yang Bebas dari Korupsi”, Downloaded October 28, 2016, from www.odazzander.com.

${ }^{2}$ Stephen P. Robbins, Organizational Behavior, NJ: Prentice Hall, 2000, 70.

${ }^{3}$ Allen \& Natalie J. Allen and John P. Meyer, "Affective, continuance, and normative commitment to the organization: an examination of construct validity", Journal of vocational behavior, Volume 49, Number 3 (1996), 252-276.

${ }^{4}$ Kementerian Agama dan Tantangan Transformasi Budaya (Menyambut Hari Amal Bhakti ke-69 Kementerian Agama). Downloaded March 13, 2016, from www.kemenag.go.id.
} 
as changing the unintegrated culture, overlapped legislation, redundant and inefficient organizational structure, slow and inefficient business process, governance, incompetence and unprofessional human resources, corruption, collusion and nepotism, up to the issue of unresponsive and unaccountable services to the public. ${ }^{5}$

The work culture in the Ministry of Religious Affairs is in line with the values of spirituality. The spiritual values refer to honesty, integrity, good quality work, responsibility, caring to colleagues and subordinates as well as socially responsible to the environment and community. ${ }^{6}$ Some of the major companies in the world and in Indonesia have participated in spirituality training. Approximately, there are 67,000 employees of Pacific Bell in California who participated in spiritual training as the style of New Age. That action was followed by Procter \& Gamble, Ford Motor Company, AT \& T, General Motors, and IBM. ${ }^{7}$ Some companies in Indonesia such as Garuda Indonesia, Krakatau Steel, Pertamina, Pusri, and TASPEN have sent their executives to join spiritual training. ${ }^{8}$

The spiritual training valued and respected employees' emotion, thus they can determine their own destiny ${ }^{9}$. The results of the previous research show that work spirituality is an important factor for improving business performance ${ }^{10}$, avoiding moral stress, personality dissociation,

${ }_{5}$ Tantangan Birokrasi Pemerintahan Jokowi-JK. Retrieved March 13, 2016, from:www.kompas.com.

${ }^{6}$ Corinne McLaughlin, "Spirituality and Ethics in Business", Retrieved February 12, 2016, from www.visionarylead.org.

${ }^{7}$ John Naisbitt and Patricia Aburdene, Megatrends 2000, Jakarta: Binarupa Aksara, $1990,56$.

${ }^{8}$ Soejitno Irmim and Abdul Rochim, Menuju Bisnis yang Islami, Jakarta: Seyma Media, 2006, 20.

${ }^{9}$ Arménio Rego and Miguel Pina e Cunha,"Workplace spirituality and organizational commitment: an empirical study", Journal of Organizational Change Management, Volume 21, Number 1 (2008), 54.

10 Pooja Garg and Renu Rastogi, "New model of job design: Motivating employees performances”, Journal of Management Development Vol. 25 Issue 6 (2006), 580. 
or loss of personal integrity. ${ }^{11}$

Spirituality is the innate part of a human that needs to connect with something larger than ourselves. It means something beyond us, the ego or sense of oneself. It is defined as a vertical and horizontal component. The vertical component includes something sacred, divine, or eternal, meanwhile horizontal components include service to fellow human beings. ${ }^{12}$

\section{Literature review and hypothesis development}

The research on spirituality associated with organizational commitment which studied 361 people across 154 organizations shows that when someone has a spirituality of work experience, the affective commitment to the organization will be attached, in this case, the experience as a sense of loyalty. ${ }^{13}$ Self-leadership made employees have a spiritual experience in the organization. ${ }^{14}$ Spirituality predicts affective commitment among employees. ${ }^{15}$ Malik and Naeem (2010) Spiritual dimensions such as selfdetermination, organization mode, transaction mode, self-control, a small group mode, transformational mode, and self-enrichment are related to organizational commitment. ${ }^{16}$

${ }^{11}$ Johan Graffland, Muel Kaptein and Corrie Mazereeuw-van der Duijn Schouten, "Business dilemmas and religious belief: an explorative study among Dutch executive", Journal of Business Ethics, Volume 66 (2006), 53.

${ }^{12}$ Cindy Wigglesworth, "Spiritual intelligence and why it matters", Downloaded on January 2, 2016, from www.deepchange.com

${ }^{13}$ Arménio Rego and Miguel Pina e Cunha," Workplace spirituality and..., 56.

${ }^{14}$ Christopher Neck, Milliman P, and John F, "Thought self-leadership: Finding spiritual fulfillment in organizational life", Journal of Managerial Psychology, Bradford, Volume 9, Number 6 (1994), 11.

${ }^{15}$ Ali Usman and Rizwan Qaiser Danish, "Leadership spirituality in banking professionals and its impact on organizational commitment", International Journal of Bussines and Management, Volume 5, Number 3 (2010), 189.

${ }^{16}$ Muhammad Ehsan Malik and Basharat Naeem, "Role of spirituality in job satisfaction and organizational commitment among faculty of institutes of higher learning in Pakistan.”, African Journal of Business Management, Volume 5, Number 4 (2011), 1240. 
In contrast to the above study, spirituality does not always affect organizational commitment. ${ }^{17}$ A study also conducted on 163 full-time nontraditional students who attend business school in the Southeast and working professionals at the managerial level. The results show that workplace spirituality, workplace spirituality by age, and workplace spirituality by gender do not affect organizational commitment. ${ }^{18}$

The research shows inconsistency in the results. The inconsistent results above lead to the assumption that there is a moderating variable. Researchers propose that a dual career family worker is the moderating variable in the influence of spirituality on organizational commitment. The novelty of this research lies on the organizational commitment topics with the dual-career family-worker as a moderating variable in the influence of spirituality on organizational commitment. To the knowledge of the researchers, there is no research on the topic.

The basis for selecting the dual-career family-worker as a moderating variable based on the transformation of the workplace, which leads to an increase in dual-career families. Social trends changed, such as the increasing number of women entering the workforce and the economy that requires a double income to support the average of living standards. ${ }^{19}$

In the late 1950s, there was an increasing attention to families where both husband and wife become partners. ${ }^{20}$ According to the Census $\mathrm{Bu}$ -

${ }^{17}$ Sanders III, Joseph E. Hopkins, Willie E. and Gary D Geroy, “ A Causal Assessment of the Spirituality-Leadership-Commitment Relationship”, Journal of Management, Spirituality $\mathcal{E}$ Religion, Volume 2, Number 1 (2005), 45.

${ }^{18}$ Eleanor Marschke, Robert Preziosi, and William Harrington, "Professional and executives support relationship between organizational commitment and spirituality in the workplace", Journal of Business and Economics Research, Volume 7, Number 8 (2009), 33.

${ }^{19}$ Kelly L Brunning, "Quality of work life issues, the needs of the dual career couple employee perceptions of personnel practices: a study of rural America barometer for human resource managers", Journal of Organizational Culture, Communications, and Conflict, Volume 8 (2004), 7.

${ }^{20}$ C. N. Cobb. Jordan and R. McCully. "Clinical issues of the dual-career couple", Social Work, Volume 34 (1989), 29. 
reau in 1997, 17 \% of all families in the US has household income derived from the father (husband). Married couples with children where the husband and wife work were accounted for $50.9 \%$ of the labor force in $2003 .{ }^{21}$

In addition to the above reasons, research on marital status that is associated with organizational commitment shows that marital status is associated with lower continuance commitment. ${ }^{22}$ When organizational commitment compared between dual and single income family, it was found that single income family had a higher organizational commitment than the dual income family ${ }^{23}$. In contrast, a study shows that dual wage-earner family had a higher organizational commitment than single wage-earner family. ${ }^{24}$

Organizational commitment consists of three components (commitment) namely affective, continuance, and normative commitment. ${ }^{25}$ Affective commitment refers to employee's emotion and identification with the organization. Individuals with high levels of affective commitment will stay working in an organization because they want it. Continuance commitment refers to awareness of the costs that arise due to leaving an organization. So people who have a high level of continuance commitment will remain in the organization because they need to. Normative commitment reflects the sense of responsibility to stay in the organization. Individuals who have a high normative commitment will stay

${ }^{21}$ Bureau of Labor Statistics 2004. Downloaded on January 11, 2014, from www.bls.gov.

${ }^{22}$ Therese A. Joiner, and Steve Bakalis, "The antecedents of organizational commitment the case of Australian casual academics", International Journal of Educational Management, Volume. 20, Number 6 (2006), 440.

${ }^{23}$ David F. Elloy, and W Randolph Flynn, "Job involvement and..., 95.

${ }^{24}$ Colin P. Silverthorne, Organizational Psychology..., 101.

${ }^{25} \mathrm{NJ}$ Allen and JP Meyer, "The measurement and antecedent of affective, continuance and normative commitment to the organization", Journal of Occupational Psychology, Volume 63 (1990), 11. 
in an organization because they feel obligated to stay (relating to loyalty). Personal variables such as age, years of employment, education level, marital status, having children who are still in the home, and the type of job changes, are strongly associated with organizational commitment. ${ }^{26}$

This research uses the Organizational Support Theory or Perceived Organizational Support (POS). The theory assumes that in order to meet the emotional needs of social and organizational readiness in giving rewards, the organization has to increase their business and employee confidence about how organizations assess their contribution and cared about their performance. ${ }^{27}$ Organizational support has positive effects on organizational commitment. ${ }^{28}$ Moreover, company concern to the employee will be able to increase its performance and contribution. ${ }^{29}$

The studies about spirituality, which associated with organizational commitment, shows that when a person has a spirituality of work, the affective commitment to the organization will be attached ${ }^{30}$ who investigated 361 individuals in 154 organizations. Workplace spirituality is the sense of team community, alignment with organizational values, sense of contribution to society, enjoyment at work, and opportunities to enrich inner life. ${ }^{31}$ Organizational commitment namely affective, normative, and continuance. ${ }^{32}$ The presence of workplace spirituality will support organizational commitment and both individual and organizational per-

${ }^{26}$ Col Cesim Demir, Bayram Sahin, Col Kadir Teke, Col Muharem Ucar and Olcay Kursun, "Organizational commitment of military physicians", Military Medicine, Volume 174, Number 9 (2009), 931.

${ }^{27}$ R. Huntington Eisenberger, R. Hutchison, S and Sowa D, "Perceived organizational support, Journal of Applied Psychology, Volume 71 (1986), 501.

${ }^{28}$ U. Colakoglu, and O. Culha, "The effect of perceived organizational support on employees' affective outcomes: evidence from the hotel industry", Tourism and hospitality management, Volume 16, Number 2 (2010), 125-150.

${ }^{29}$ Allen \& Natalie J. and John P. Meyer, "Affective, continuance, and..., 261.

${ }^{30}$ Arménio Rego and Miguel Pina e Cunha, "Workplace spirituality and..., 55.

${ }^{31}$ Arménio Rego and Miguel Pina e Cunha, "Workplace spirituality and ..., 56.

${ }^{32}$ NJ Allen and JP Meyer, "The measurement and..." 3. 
formance. When the organization satisfies the needs of members spiritually, they will feel safe psychologically and feel valued as human beings. ${ }^{33}$

Results of Rego and Cunha ${ }^{34}$ research is supported by Wainaina, Iravo, Waititu, ${ }^{35}$ Sorizeni, Kamalipur, Qhalandarzehi, Jamshidzehi, ${ }^{36}$ Torkamani, Naami, Sheykhshabani, Beshlide. ${ }^{37}$ The results of these studies are different from Marschke ${ }^{38}$ and Wainaina ${ }^{39}$ who investigate the effect of workplace spirituality on organizational commitment in 27 private universities and 22 public universities in Kenya. The samples used in the study are 282 employees at the university. The results show that there is a positive effect of workplace spirituality on organizational commitment.

Workplace spirituality has an effect on organizational commitment. The study conducted on 67 employees who work at the Agricultural Jihad Organization in Iran. Research result shows that workplace spirituality organizational commitment. ${ }^{40}$

The influence of spiritual leadership on organizational commitment, productivity, and performance with spiritual well-being and learning organization as mediating variables was conducted on 400 workers at a gas

${ }^{33}$ Arménio Rego and Miguel Pina e Cunha, "Workplace spirituality and..., 57.

${ }^{34}$ Arménio Rego and Miguel Pina e Cunha, "Workplace spirituality and..., 58.

${ }^{35}$ Lawrence Wainaina, Mike Iravo, Anthony Waititu, "Workplace spirituality as ..., a determinant of organizational commitment amongst academic staff in the private and public universities in Kenya.", International Journal of Academic Research in Business and Social Science, Volume 4, Number 12 ( 2014), 60.

${ }^{36}$ Zakaria Sorizeni, Naser Kamalipur, Keramat Qhalandarzehi, and Abdul Aziz Jamshidzehi," Studying the impact of workplace spirituality on organizational commitment (case study: agricultural jihad organization in Khash City)", International Journal of Academic Research in Business and Social Sciences, Volume 4, Number 6 (2014), 10.

${ }^{37}$ Z Torkamani, Najafluye, A. Z Naami, S. E. Sheykhshabani, Hasbemi. K Beshlide, "The effect of..., 135.

${ }^{38}$ Eleanor Marschke, Robert Preziosi, and William Harrington, "Professional and executives...., 35 .

${ }^{39}$ Lawrence Wainaina, Mike Iravo, Anthony Waititu, "Workplace spirituality as..., 281.

${ }^{40}$ Zakaria Sorizeni, Naser Kamalipur, Keramat Qhalandarzehi, and Abdul Aziz Jamshidzehi," Studying the impact..., 9. 
plant in Iran. ${ }^{41}$ The result is in line with that of Vanderberghe ${ }^{42}$ who examines the influence of spiritual leadership on employee commitment.

A study was conducted on 121 branch managers, area managers, and regional managers in private banking and the government in Pakistan which study about spiritual leadership and organizational commitment shows that spirituality predicts affective commitment among employees. ${ }^{43}$ The research is supported by Malik and $\mathrm{Naeem}^{44}$ who study the Higher Education Institution members in Pakistan which consist of three public institutions and five private institutions. Based on the results above and the theory of Perceived Organizational Support the research hypothesis is: $H_{1 a}$ : Spirituality positively influences organizational commitment.

The dual career couple and organizational commitment research were conducted to the 70 working couple in India, US, Canada, and Australia in some sectors such as IT, telecommunications, healthcare, counseling, education, and manufacture. The results show that couples with children under two years old have less time with their children because of the increasing pressure of work. It leads to a high rate of absenteeism, turnover, and low organizational commitment. ${ }^{45}$

Kaur and Kumar's ${ }^{46}$ research result is in line with Balmforth and Gardner ${ }^{47}$ in New Zealand and Nart and Batur ${ }^{48}$ in Turkey. They state

${ }^{41}$ Z Torkamani, Najafluye, A. Z Naami, S. E. Sheykhshabani, Hasbemi. K Beshlide, "The effect of..., 134.

${ }^{42}$ Christian Vanderberghe, "Workplace spirituality and organizational commitment; an integrative model", Journal of Management, Spirituality, and Religion, Volume 8, Number 3 (2011), 215.

${ }^{43}$ Ali Usman and Rizwan Qaiser Danish, "Leadership spirituality in..., 3, 189.

${ }^{44}$ Muhammad Ehsan Malik and Basharat Naeem, "Role of spirituality in..., 1237.

${ }^{45}$ Gurvinder Kaur, and Raj Kumar, "Organisational work pressure..., 584.

${ }^{46}$ Gurvinder Kaur, and Raj Kumar, "Organisational work pressure..., 585.

${ }^{47} \mathrm{~K}$ Balmforth, and D Gardner, "Conflict and facilitation between work and family: realizing the outcomes for organizations", New Zealand Journal of Psychology, 35/2 (2006), 70.

${ }^{48}$ Senem Nart, and Ozgur Batur, "The relation between work-family conflict, job stress, and organizational commitment and job performance: a study on Turkish primary teacher", European Journal of Research and Education, Volume 2, Number 2 (2014), 73. 
that dual career family worker negatively affects organizational commitment. Balmforth and Gardner ${ }^{49}$ conduct a study on 75 employees in New Zealand. Nart and Batur ${ }^{50}$ conduct a study on 266 public school teachers in Turkey. The research is supported by Kossek and Ozeki ${ }^{51}$ and Namasivayam and Zhao ${ }^{52}$ in India.

Organizational commitment is higher in the single income family than in the dual income family. ${ }^{53}$ The research examined two manufacturing companies in the US with 260 respondents for the first company and 314 respondents for the second company. Based on the above results, the next hypothesis of this study is: $\mathrm{H}_{1 b}$ : Dual-Career Family Worker moderates the influence of spirituality on organizational commitment.

Several studies on the influence of demographic factors on organizational commitment use age and tenure as demographic variables. The effect of employee's age on organizational commitment has been investigated by Konya et al., ${ }^{54}$ Ossei et al., ${ }^{55}$ Jena, ${ }^{56}$ Viet,${ }^{57}$ Khan et al., ${ }^{58}$ Yucel

${ }^{49} \mathrm{~K}$ Balmforth, and D Gardner, "Conflict and facilitation..., 71.

${ }^{50}$ Senem Nart, and Ozgur Batur, "The relation between..., 73.

${ }^{51}$ E. E. Kossek, and C. Ozeki, "Work-family conflict, policies and the job-life satisfaction relationship: a review and directions for organizational behavior human resource research", Journal of Applied Psychology, Volume 82, Number 2 (1998), 141.

${ }^{52} \mathrm{~K}$. Namasivayam, and X. Zhao, "An investigation of the moderating effects of organizational commitment on the relationship between work-family conflict and job satisfaction among hospitality employees in India”, Tourism Management, Volume 28, Number 5 (2006), 1213.

${ }^{53}$ David F. Elloy, and W Randolph Flynn, "Job involvement and..., 71.

${ }^{54}$ Valentin Konya, Dejan Matic, and Jasmina Pavlovic, "The Influence of Demographic, Job Characteristics and Characteristics of Organizations on Employee Commitment", Acta Polytechnica Hungaria, Volume 13, Number 3 (2016), 120.

${ }^{55}$ Emmanuel Affum-Osei, Ebenezer Acquaah, Phinihas Acheampong, "Relationship between Organisational Commitment and Demographic Variables: Evidence from Commercial Bank in Ghana", American Journal of Industrial and Business Management, Volume 5 (2015), 770.

${ }^{56}$ R. K Jena, "An assessment of Demographic Factors Affecting Organizational Commitment among Shift Workers in India", Management, Volume 20, Number 1 (2015), 60.

${ }^{57}$ Vo Van Viet, "Demographic Factors Affecting Organizational Commitment of Lecturers”, Journal of Science: Education Research, Volume 31, Number 4 (2015), 17.

${ }^{58}$ Irfanullah Farhatullah Khan, Hamid Khan, Allah Nawaz, Naseem Bakht Yar, "Determining the Demographic Impacts on the Organizational Commitment of Academicians 
and Bektas, ${ }^{59}$ Iqbal, ${ }^{60}$ and Salami., ${ }^{61}$ The influence of the employees' tenure on organizational commitment has been investigated by Konya et al., ${ }^{62}$ Ossei et al., ${ }^{63}$ Jena, ${ }^{64}$ Viet,${ }^{65}$ Iqbal, ${ }^{66}$ Pala et al., ${ }^{67}$ and Salami. ${ }^{68}$

Personal characteristics, job-related characteristics, and job involvement characteristics on organizational commitment. The results show that personal characteristics (gender, marital status, family responsibility, and education) affect organizational commitment. The research examines academic employees who work at the university in Australia. ${ }^{69}$

The effect of demographic characteristics and job characteristics on organizational commitment in Serbia's Central European Organization. The samples are 891 respondents who returned the questionnaire out of 1400 respondents. The study was conducted in 2012-2014. Research results indicate that gender does not affect organizational commitment,

in the HEIs of DCs like Pakistan”, European Journal of Sustainable Development, Volume 2, Number 4 (2013), 118.

${ }^{59}$ Ilhami Yucel, Cetin Bektas, "Job Satisfaction, Organizational Commitment and Demographic Characteristics among Teachers in Turkey: Younger is Better?", Procedia Social and Behavioral, Volume 46 (2012), 1599.

${ }^{60}$ Adnan Iqbal, "An Empirical Assessment of Demographic Factors, Organizational ranks, and Organizational Commitment", International Journal of Business and Management, Volume 5, Number 3 (2010), 18.

${ }^{61}$ Samuel O Salami, "Demographics and Psychological Factors Predicting Organizational Commitment among Industrial Workers", Anthropologist, Volume 10, Number 1 (2008), 32.

${ }^{62}$ Valentin Konya, Dejan Matic, and Jasmina Pavlovic, "The Influence of..., 120.

${ }^{63}$ Emmanuel Affum-Osei, Ebenezer Acquaah, Phinihas Acheampong, "Relationship between Organisational..., 771.

${ }^{64}$ R. K Jena, "An assessment of..., 60.

${ }^{65}$ Vo Van Viet, " Demographic Factors Affecting..., 18.

${ }^{66}$ Adnan Iqbal, "An Empirical Assessment of..., 18.

${ }^{67}$ Fikri Pala, Eker Semin, Melele Eker, "The Effects of Demographic Characteristics on Organizational Commitment and Job Satisfaction: An Empirical Study on Turkish Health Care Staff", The Journal of Industrial Relations and Human Resources, Volume 10, Number 2 (2008), 60.

${ }^{68}$ Samuel O Salami, "Demographics and Psychological..., 32.

${ }^{69}$ Therese A. Joiner, and Steve Bakalis, "The antecedents of..., 584. 
demographic characteristics (age, tenure, education, a total of servicing years) only have a small effect on organizational commitment and job characteristics has a strong effect on organizational commitment. ${ }^{70}$

A study that was conducted at the Nong Lam university lecturer, Ho Chi Minh in Vietnam about the correlation between age and organizational commitment shows that there is a weak negative correlation between age and normative commitment ${ }^{71}$. In contrast, a research which examines the relationship between demographic factors (age, duration of service, and level of education) and organizational commitment shows that age and education levels do not correlate with the organizational commitment. The study was conducted in an organization of Knitwear in Lahore and Faisalabad, Pakistan and used a sample of 415 employees. $^{72}$

A research which is held in Pakistan investigate the influence of demographic factors such as gender, age, qualifications, and marital status on organization commitment in the University of Khyber Pakhtunkhwa employees. ${ }^{73}$ Research results show that demographic factors affect organizational commitment. Researchers also find that younger employees are less committed to the organization.

The investigation about age, job satisfaction, and organizational commitment of teachers in Turkey conducted on 173 respondents. The results show that the age differences among teachers moderate the relationship between organizational commitment and job satisfaction. The effect of this variable is non-linear. ${ }^{74}$

\footnotetext{
${ }^{70}$ Valentin Konya, Dejan Matic and Jasmina Pavlovic, "The Influence of..., 121.

${ }^{71}$ Vo Van Viet," Demographic Factors Affecting..., 17.

${ }^{72}$ Adnan Iqbal, "An Empirical Assessment of..., 20.

${ }^{73}$ Irfanullah Farhatullah Khan, Hamid Khan. Allah Nawaz. Naseem Bakht Yar,"Determining the Demographic Impacts on..., 118.

${ }^{74}$ Ilhami Yucel, Cetin Bektas, "Job Satisfaction, Organizational..., 1599.
} 
The influence of age, gender, job level, marital status, and tenure on organization commitment in the industrial field in Odisha India through 240 employees indicates that age has a positive influence on affective and normative commitment. Marital status influences affective, normative, and continuance commitment. Tenure has a positive effect on affective commitment, job level influences affective and continuance commitment, and gender influences affective and normative commitment ${ }^{75}$. The results of the study are consistent with Salami ${ }^{76}$ who states that the age of the employee is the determining factor of organizational commitment.

The influence of demographic factors such as age, marital status, experience, qualifications, and gender on organizational commitment in Ghana, used 206 sample employees of a commercial bank in Ghana and the results show that demographic factors influence organizational commitment generally. Age positively influence organizational commitment. Researchers also find that gender has little influence on organizational commitment, while the dominant demographic factors affect is the experience. ${ }^{77} \mathrm{H}_{2 a}$ : Age positively influences organizational commitment.

The results of studies on the effects of age on organizational commitment conducted by Kaur and Kumar, ${ }^{78}$ Balmforth and Gardner, ${ }^{79}$ Nart and Batur ${ }^{80}$ show that dual career family worker negatively affects organizational commitment. This evidence has reinforced a research ${ }^{81}$ which find that there are differences in organizational commitment between

\footnotetext{
${ }^{75}$ R. K Jena, "An assessment of..., 61.

${ }^{76}$ Samuel O Salami,"Demographics and Psychological..., 33.

${ }^{77}$ Emmanuel Affum-Osei, Ebenezer Acquaah, Phinihas Acheampong, "Relationship between Organisational..., 770.

${ }^{78}$ Gurvinder Kaur, and Raj Kumar, "Organisational work pressure..., 585.

${ }^{79} \mathrm{~K}$ Balmforth, and D Gardner, "Conflict and facilitation..., 72.

${ }^{80}$ Senem Nart, and Ozgur Batur, "The relation between..., 73.

${ }^{81}$ David F. Alloy and W Randolph. Flynn, "Job involvement and..., 95.
} 
single income and dual-income family as well as their changes in social trends in which more percentage of women work, ${ }^{82}$ then the hypothesis of this study is: $H_{2 b}$ : Dual-Career Family Worker moderates the influence of age on organizational commitment.

The result of research conducted in Serbia ${ }^{83}$ shows that demographic factor such as tenure gives only a small effect on organizational commitment. The result was supported by Viet (2015) in Vietnam who states that the correlation between years of work and continuance commitment is weak.

The results were slightly different from a research conducted in Ghana ${ }^{84}$ who find that experience measured using tenure has a positive effect on organizational commitment. The results of their study are consistent with Iqbal ${ }^{85}$ who find that the duration of service measured using tenure has a positive relationship with organizational commitment. This result is supported by Jena ${ }^{86}$ in India, who states that tenure has a positive effect on employees' affective commitment. The results of the study are consistent with Salami ${ }^{87}$ research in Nigeria which find that tenure becomes the determining factor of organizational commitment. Salami ${ }^{88}$ conducts a study on 320 employees at five service companies and five manufacturing companies in the Oyo State of Nigeria. $\mathrm{H}_{3 a}$ : Tenure positively influences organizational commitment.

Research conducted by Kossek and Ozeki ${ }^{89}$ and Namasivayam and Zhao $^{90}$ in India find that dual-career family worker negatively affects or-

\footnotetext{
${ }^{82}$ Kelly L. Brunning, "Quality of work..., 5.

${ }^{83}$ Valentin Konya, Dejan Matic, and Jasmina Pavlovic, "The Influence of..., 30.

${ }^{84}$ Emmanuel Affum-Osei, Ebenezer Acquaah, Phinihas Acheampong, "Relationship between Organisational..., 932.

${ }^{85}$ Adnan Iqbal, "An Empirical Assessment of..., 19.

${ }^{86}$ R. K Jena, "An assessment of..., 60.

${ }^{87}$ Samuel O Salami,"Demographics and Psychological..., 36.

${ }^{88}$ Samuel O Salami,"Demographics and Psychological..., 34.

${ }^{89}$ E. E. Kossek, and C. Ozeki, "Work-family conflict..., 142.

${ }^{90}$ K. Namasivayam, and X. Zhao, "An investigation of..., 1214.
} 
ganizational commitment. This finding is relevant to the research conducted in India, US, Canada, and Australia. ${ }^{91}$ The finding is also reinforced by the research which find that there were differences in organizational commitment between single income and dual-income family as well as their changes in social trends in which more percentage of women work, ${ }^{92}$ thus the hypothesis of this study is: $\mathrm{H}_{36}$ : Dual-Career Family Worker moderates the influence of tenure on organizational commitment.

Based on that explanation, the conceptual framework of this study is:

Figure 1. The Conceptual Framework

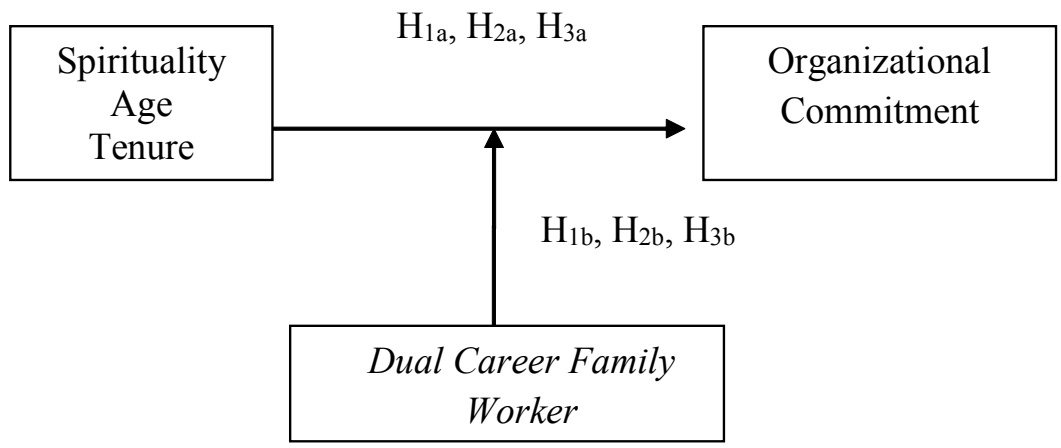

According to Figure 1 The Conceptual Framework, the independent variables in this research are spirituality, age, and tenure, the dependent variable is organizational commitment and the moderating variable is dual career family worker.

\section{Research method}

The population of this study is employees who work in the Ministry of Religious Affairs at the Republic of Indonesia especially in IAIN Surakarta (246 employees), IAIN Salatiga (166 employees), and MTsN 1 Surakarta

\footnotetext{
${ }^{91}$ Gurvinder Kaur, and Raj Kumar, "Organisational work pressure..., 46.

${ }^{92}$ Kelly L Brunning, "Quality of work life..., 6.
} 
(employees). This study uses employees who work at the Ministry of Religious Affairs because it is in line with the phenomenon in this research namely Saifuddin statement, the Minister of Religious Affairs, about The Five Work Culture developed in the Ministry of Religious Affairs. IAIN Surakarta, IAIN Salatiga, and MTsN 1 Surakarta are selected as the object of the study because there is no research about organizational commitment in those institutions. It becomes the second differentiator of this study compared to other studies in addition to the use of dual career family worker variable as a moderating variable. Total population in this study is 440 employees. The sampling technique used in this study is purposive sampling with the following criteria: a) Civil Servants in the Ministry of Religious Affairs; b) Having a husband/wife of a civil servant or an employee in Ministry of Religious Affairs or another institution.

The questionnaire was distributed to 120 respondents and 90 questionnaires returned. This data collection method is administrated questionnaires personally. The questionnaire is divided into three parts namely: a) The first part is about organizational commitment including affective, continuance, and normative commitment which refers to Allen and Meyer $^{93}$; b) The second part is about spirituality which refers to Spirituality Transcendence Scale ${ }^{94}$; c) The third part about Dual-Career Family Worker which refers to Revised Dyadic Adjustment Scale (RDAS). ${ }^{95}$

Validity test and reliability test are used to test the instrument of the research. The hypothesis testing in this study is performed using Moderated Regression Analysis (MRA) with the assistance of software SPSS version 20.00. The research model is as follows:

\footnotetext{
${ }^{93}$ NJ Allen and JP Meyer, "The measurement and..., 11.

${ }^{94}$ G.T Reker, Provisional Manual of the Spiritual Transcendence Scale (STS-24), Peterborough: Student Psychologists Press, 2003.

${ }^{95}$ D. R. Middleton Crane, K. C. and Bean, R. A. "Establishing criterion score for the Kansas Marital satisfaction scale and the revised dyadic adjustment scale", American Journal of Family Therapy, Volume 28, Number 1 (2000), 55.
} 
$\mathrm{OC}=\mathrm{a}+\mathrm{b}_{1} \mathrm{~S}+\mathrm{b}_{2} \mathrm{AGE}+\mathrm{b}_{3}$ TENURE $+\mathrm{b}_{4} \mathrm{DCFW}+\mathrm{b}_{5} \mathrm{SDCFW}+$ $\mathrm{b}_{6} \mathrm{AGEDCFW}+\mathrm{b}_{7}$ TENUREDCFW $+\mathrm{e}$

Note:

OC : organizational commitment

$\mathrm{S} \quad$ : spirituality

AGE : age

TENURE : tenure

DCFW dual career family worker

SDCFW : interaction between spirituality and dual career family worker

AGEDCFW : interaction between age and dual career family worker TENUREDCFW : interaction between tenure and dual career family worker e : standard error

All of the 33 questions in the questionnaire are valid with the 0.01 level. Organizational commitment, spirituality, and dual career family worker variables meet the minimum required values of Cronbach's Alpha $>0.6$, so all the questions are reliable. Based on the test for normality, multicollinearity, and heteroscedasticity, it can be concluded that the variables used in this study have passed the classical assumption test.

\section{Hypothesis testing and discussion}

The results of the hypothesis testing can be seen in Table 1 Moderated Regression Analysis Output below: 
Table 1. Moderated Regression Analysis Output

\begin{tabular}{lll}
\hline \multicolumn{1}{c}{ Variables } & Coefficient & \multicolumn{1}{c}{ p-value } \\
\hline Constant & 2.692 & 0.672 \\
S & 0.244 & $0.000^{* * *}$ \\
AGE & 0.194 & 0.328 \\
TENURE & 0.401 & $0.044^{* *}$ \\
DCFW & 0.050 & 0.773 \\
SDCFW & 0.051 & $0.000^{* * *}$ \\
AGEDCFW & -0.018 & 0.367 \\
TENUREDCFW & 0.037 & $0.073^{*}$ \\
\hline Adj. ${ }^{2}$ & 0.420 & \\
F-Statistic & 10.197 & \\
Probability (F- & 0.000 & \\
statistic) & \\
N & 90 & \\
***** ${ }^{*}$ significant in $0.01 ; 0.05 ; 0.1$ & \\
Source: data processed
\end{tabular}

The equations model based on the MRA is as follows:

$\mathrm{OC}=2.692+0.244 \mathrm{~S}+0.194 \mathrm{AGE}+0.401 \mathrm{TENURE}+0.050 \mathrm{DCFW}+$ 0.051SDCFW - 0.018AGEDCFW + 0.037TENUREDCFW + e

Table 1 Moderated Regression Analysis Output shows that spirituality has a positive effect on organizational commitment (coefficient 0.244 with sig. $0.000<0.05)$, so $\mathrm{H}_{1 \mathrm{a}}$ is supported. The result is not in line with Sanders and Joseph E. ${ }^{96}$ and Marschke ${ }^{97}$ research which find that there is no significant causal relationship between spirituality and commitment. This result supports the research conducted by Rego and Cunha, ${ }^{98}$ Usman

\footnotetext{
${ }^{96}$ Sanders III, Joseph E. Hopkins, Willie E. and Gary D Geroy, "A Causal Assessment..., 50.

${ }^{97}$ Eleanor Marschke, Robert Preziosi, and William Harrington, "Professional and executives..., 40.

${ }^{98}$ Arménio Rego and Miguel Pina e Cunha,"Workplace spirituality and..., 60.
} 
and Danish, ${ }^{99}$ Wainaina et al., ${ }^{100}$ Sorizeni et al., ${ }^{101}$ and Torkamani et al. ${ }^{102}$ This result reflects that employees get adequate social and emotional needs, so they feel valued and appreciated, and thus their organizational commitment is higher.

Dual Career Family Worker moderates the influence of spirituality on organizational commitment (coefficient 0.051 with sig $0.000<0.05$ ), so that the $\mathrm{H}_{1 \mathrm{~b}}$ is accepted. It can be caused by a greater burden of work and family in Dual-Career Family Worker, so if there is a conflict in their role, it will weaken the influence of spirituality on organizational commitment. The effect of Dual Career Family Worker on organizational commitment is not proven, it is not in line with the research conducted by Kaur and Kumar, ${ }^{103}$ Balmforth and Gardner, ${ }^{104}$ Nart and Batur, ${ }^{105}$ Kossek and Ozeki, ${ }^{106}$ Alloy and Flynn, ${ }^{107}$ Joiner, ${ }^{108}$ and Namasivayam and Zhao. ${ }^{109}$ Because Dual-Career Family Worker has no effect on the organizational commitment, in this research this variable is a pure moderator.

Table 1 Moderated Regression Analysis Output shows that age does not positively affect organizational commitment (coefficient 0.194 with a sig. $0.328>0.05$ ), so $\mathrm{H}_{2 \mathrm{a}}$ is not supported. The result is not in line with

\footnotetext{
${ }^{99}$ Ali Usman and Rizwan Qaiser Danish, "Leadership spirituality in..., 189.

${ }^{100}$ Lawrence Wainaina, Mike Iravo, Anthony Waititu, "Workplace spirituality as..., 289.

101 Zakaria Sorizeni, Naser Kamalipur, Keramat Qhalandarzehi, and Abdul Aziz Jamshidzehi," Studying the impact..., 16.

102 Z Torkamani, Najafluye, A. Z Naami, S. E. Sheykhshabani, Hasbemi. K Beshlide, "The effect of..., 139.

${ }^{103}$ Gurvinder Kaur, and Raj Kumar, "Organisational work pressure..., 590.

${ }^{104} \mathrm{~K}$ Balmforth, and D Gardner,"Conflict and facilitation..., 72.

105 Senem Nart, and Ozgur Batur,"The relation between..., 79.

${ }^{106}$ E. E. Kossek, and C. Ozeki,"Work-family conflict..., 145.

107 David F. Alloy, and W Randolph Flynn,"Job involvement and..., 99.

108 Therese A. Joiner, and Steve Bakalis, "The antecedents of..., 445.

${ }^{109}$ K. Namasivayam, and X. Zhao,"An investigation of..., 1215.
} 
Konya et al. ${ }^{110}$ Viet, ${ }^{111}$ Khan et al., ${ }^{112}$ Jena, ${ }^{113}$ Yucel and Bektas, ${ }^{114}$ and Ossei et al. ${ }^{115}$ This study supports the finding of research conducted by Iqbal. It might be caused by the older employees, they have more seniority in the organization, and many parties used his services besides his organization increasingly because of his reputation. Another reason is the health condition of the employee due to the age.

Dual Career Family Worker does not moderate the influence of age on organizational commitment (coefficient -0.018 with sig $0.367>0.05$ ) so that $\mathrm{H}_{2 \mathrm{~b}}$ is not supported. It might be caused by a greater burden of work and family in Dual-Career Family Worker, so if there is a conflict in their role, it will weaken the influence of age on organizational commitment. The effect of Dual Career Family Worker on organizational commitment is not proven, it is not in line with the research conducted by Kaur and Kumar, ${ }^{116}$ Balmforth and Gardner, ${ }^{117}$ Nart and Batur, ${ }^{118}$ Kossek and Ozeki, ${ }^{119}$ Alloy and Flynn, ${ }^{120}$ Joiner, ${ }^{121}$ and Namasivayam and Zhao. ${ }^{122}$

Table 1 Moderated Regression Analysis Output shows that tenure has a positive effect on organizational commitment (coefficient 0.401 with a sig. $0.044<0.05)$, so $\mathrm{H}_{3 \mathrm{a}}$ is supported. This study supports the research

${ }^{110}$ Valentin Konya, Dejan Matic, and Jasmina Pavlovic,"The Influence of..., 135.

${ }^{111}$ Vo Van Viet," Demographic Factors Affecting..., 20.

112 Irfanullah Farhatullah Khan, Hamid Khan, Allah Nawaz, Naseem Bakht Yar,"Determining the Demographic Impacts on..., 125.

${ }^{113}$ R. K Jena, "An assessment of..., 72.

${ }^{114}$ Ilhami Yucel, Cetin Bektas,”Job Satisfaction, Organizational..., 1601.

115 Emmanuel Affum-Osei, Ebenezer Acquaah, Phinihas Acheampong,"Relationship between Organisational..., 775 .

116 Gurvinder Kaur, and Raj Kumar,"Organisational work pressure..., 592.

${ }^{117} \mathrm{~K}$ Balmforth, and D Gardner,"Conflict and facilitation..., 74.

118 Senem Nart, and Ozgur Batur,"The relation between..., 79.

${ }^{119}$ E. E. Kossek, and C. Ozeki,"Work-family conflict..., 145.

${ }^{120}$ David F. Alloy, and W Randolph Flynn,"Job involvement and..., 98.

${ }^{121}$ Therese A. Joiner, and Steve Bakalis, "The antecedents of..., 449.

${ }^{122}$ K. Namasivayam, and X. Zhao,"An investigation of..., 1220. 
conducted by Ossei et al., ${ }^{123}$ Jena, ${ }^{124}$ Iqbal, ${ }^{125}$ and Salami. ${ }^{126}$ It might be caused by that the longer the workers stay with the organization, the more they have time to evaluate, and develop the relationship with the organization. Moreover, the longer they work in the organization, the stronger the emotional attachment so that tenure influences organizational commitment.

Dual Career Family Worker moderates the influence of tenure on organizational commitment (coefficient 0.037 with sig $0.073<0.1$ ), so that $\mathrm{H}_{3 \mathrm{~b}}$ is supported. It can be caused by no greater burden on work and family in Dual-Career Family Worker, so if there is no conflict in their role, the stronger the influence of tenure on organizational commitment. The greater perceived responsibility on a dual career family worker and the longer the employee works, the more employees attached emotionally to the organization, so that the commitment to the organization increases.

Effect of Dual Career Family Worker on organizational commitment is not proven, it is not in line with the research conducted by Kaur and Kumar ${ }^{127}$, Balmforth and Gardner, ${ }^{128}$ Nart and Batur, ${ }^{129}$ Kossek and Ozeki, ${ }^{130}$ Alloy and Flyn, ${ }^{131}$ Joiner, ${ }^{132}$ and Namasivayam and Zhao. ${ }^{133}$ Because Dual-Career Family Worker has no effect on the organizational

${ }^{123}$ Emmanuel Affum-Osei, Ebenezer Acquaah, Phinihas Acheampong,"Relationship between Organisational..., 775 .

${ }^{124}$ R. K Jena,"An assessment of..., 76.

125 Adnan Iqbal,"An Empirical Assessment of..., 25.

126 Samuel O Salami,"Demographics and Psychological..., 35.

127 Gurvinder Kaur, and Raj Kumar, "Organisational work pressure..., 590.

${ }^{128} \mathrm{~K}$ Balmforth, and D Gardner, "Conflict and facilitation..., 72.

129 Senem Nart, and Ozgur Batur,"The relation between..., 80.

${ }^{130}$ E. E. Kossek, and C. Ozeki,"Work-family conflict..., 145.

${ }^{131}$ n David F. Alloy, and W Randolph Flynn," Job involvement and..., 99.

${ }^{132}$ Therese A. Joiner, and Steve Bakalis, "The antecedents of..., 450.

${ }^{133}$ K. Namasivayam, and X. Zhao,"An investigation of..., 1220. 
commitment, Dual-Career Family Worker in this research is included in the pure moderation.

\section{Conclusion}

Based on the above discussion, our conclusions are as follows: firstly, Spirituality influences organizational commitment positively. The implications of these results, especially for the leader of the Ministry of Religious Affairs in IAIN Salatiga, IAIN Surakarta, and MTsN 1 Surakarta is to maintain and improve the care and concern for the social-emotional needs of his subordinates (intrinsic and extrinsic reward) so that they feel valued and appreciated. Secondly, Dual Career Family Worker moderates the influence of spirituality on organizational commitment. The implication of this research is that the leader of IAIN Salatiga, IAIN Surakarta, and MTsN 1 Surakarta has to give attention to the needs of dual career family workers, mainly regarding the fulfillment of work and family balance. Thirdly, Tenure positively influences organizational commitment. The implications of these results, especially for the leadership of the Ministry of Religious Affairs in IAIN Salatiga, IAIN Surakarta, and MTsN 1 Surakarta is they should maintain and improve the care and concern for the social-emotional needs of his subordinates (intrinsic and extrinsic reward) so that they feel valued and appreciated based on the tenure of the worker. Finally, Dual Career Family Worker moderates the influence of tenure on organizational commitment. The implication of this research is that the leader of IAIN Salatiga, IAIN Surakarta, and MTsN 1 Surakarta needs to give attention to the needs of dual career family working mainly related to the fulfillment of the balance between work and family based on the tenure of the worker.

Suggestions for future research are as follows: firstly, future studies should examine different objects, different theories in organizational commitment, and different variables (independent and moderation) from 
this research. Secondly, future studies may use different methodologies such as the mixed method (quantitative and qualitative) to get new perspective in organizational commitment. Finally, future research may use other methodologies such as the usage of mediation variable.

\section{Bibliography}

Affum-Osei, Emmanuel, Ebenezer Acquaah, Phinihas Acheampong, "Relationship between Organisational Commitment and Demographic Variables: Evidence from Commercial Bank in Ghana", American Journal of Industrial and Business Management, Volume 5 (2015): 770-778.

Allen, N.J., and Meyer, J.P., "Affective, continuance, and normative commitment to the organization: an examination of construct validity", Journal of Vocational Behavior, Volume 49, Number 3 (1996): 252-276.

Allen, NJ and Meyer,JP, "The measurement and antecedent of affective, continuance and normative commitment to the organization", Journal of Occupational Psychology, Volume 63 (1990): 1-18.

Brunning, Kelly L, "Quality of work life issues, the needs of the dual career couple employee perceptions of personnel practices: a study of rural America barometer for human resource managers", Journal of Organizational Culture, Communications, and Conflict, Volume 8 (2004): 1-8.

Bureau of Labor Statistics 2004. Downloaded on January 11, 2014, from www.bls.gov.

C. N. Cobb. Jordan and R. McCully, "Clinical issues of the dual-career couple" Social Work, Volume 34 (1989): 29-32.

Colakoglu, U and Culha, O.,"The effect of perceived organizational support on employees' affective outcomes: evidence from the hotel industry", Tourism and Hospitality Management, Volume 16, Number 2 (2010): 125 150

Crane, D. R. Middleton, K. C. and Bean, R. A.,"Establishing criterion score for the Kansas Marital satisfaction scale and the revised dyadic adjustment scale", American Journal of Family Therapy, Volume 28, Number 1 (2000): 53-60.

Demir, Col Cesim; Sahin, Bayram; Teke, Col Kadir; Ucar, Col Muharem, and Kursun, Olcay, "Organizational commitment of military physicians", Military Medicine, Volume 174, Number 9 (2009): 929-935. 
Eisenberge, R. Huntington, R. Hutchison, S and Sowa D, "Perceived organizational support", Journal of Applied Psychology, Volume 71 (1986): 500507.

Elloy, David F., and W Randolph Flynn, "Job involvement and organization commitment among dual-income and single-income families: A multiplesite study", The Journal of Social Psychology, Volume 138, Number 1 (1998): 93-101.

G.T Reker. Provisional Manual of the Spiritual Transcendence Scale (STS-24). Peterborough: Student Psychologists Press, 2003.

Garg, Pooja and Rastogi, Renu, "New Model of Job Design: Motivating Employees Performances", Journal of Management Development, Vol.25 Issue 6 (2006): 572-587.

Graffland, Johan, Kaptein, Muel, and Corrie Mazereeuw-van der Duijn Schouten, "Business dilemmas and religious belief: an explorative study among Dutch executive", Journal of Business Ethics, Volume 66 (2006): 53-71

Iqbal, Adnan, "An Empirical Assessment of Demographic Factors, Organizational ranks, and Organizational Commitment", International Journal of Business and Management, Volume 5, Number 3 (2010): 16-27.

Irfanullah Farhatullah Khan, Hamid Khan, Allah Nawaz, Naseem Bakht Yar, "Determining the Demographic Impacts on the Organizational Commitment of Academicians in the HEIs of DCs like Pakistan”, European Journal of Sustainable Development, Volume 2, Number 4 (2013): 117-130.

Irmim, Soejitno and Rochim, Abdul. Menuju Bisnis yang Islami. Jakarta : Seyma Media, 2006.

Jena, R. K,"An assessment of Demographic Factors Affecting Organizational Commitment among Shift Workers in India", Management, Volume 20, Number 1 (2015): 59-77.

Joiner, Therese A. and Steve Bakalis, "The antecedents of organizational commitment the case of Australian casual academics", International Journal of Educational Management, Volume. 20, Number 6 (2006): 439-452.

$\mathrm{K}$ Balmforth, and D Gardner, "Conflict and facilitation between work and family: realizing the outcomes for organizations", New Zealand Journal of Psychology, 35/2 (2006): 69-76.

Kaur, Gurvinder and Kumar, Raj, "Organisational work pressure rings a 'timeout" alarm for children; a dual career couple's study", Asian Journal of Management Research, Volume 4, Number 3 (2014): 583-596. 
Kementerian Agama dan Tantangan Transformasi Budaya (Menyambut Hari Amal Bhakti ke-69 Kementerian Agama). Downloaded March 13, 2016, from www.kemenag.go.id.

Konya, Valentin, Dejan Matic, and Jasmina Pavlovic, "The Influence of Demographic, Job Characteristics and Characteristics of Organizations on Employee Commitment", Acta Polytechnica Hungaria, Volume 13, Number 3 (2016): 119-138.

Kossek, E. E. and C. Ozeki, "Work-family conflict, policies and the job-life satisfaction relationship: a review and directions for organizational behavior human resource research", Journal of Applied Psychology, Volume 82, Number 2 (1998): 139-149.

Malik, Muhammad Ehsan and Basharat Naeem, "Role of spirituality in job satisfaction and organizational commitment among faculty of institutes of higher learning in Pakistan", African Journal of Business Management, Volume 5, Number 4 (2011): 1236-1244.

Marschke, Eleanor Robert Preziosi, and William Harrington, "Professional and executives support relationship between organizational commitment and spirituality in the workplace", Journal of Business and Economics Research, Volume 7, Number 8 (2009): 33-48.

McLaughlin, Corinne,"Spirituality and Ethics in Business", Retrieved February 12, 2016, from www.visionarylead.org.

Naisbitt, John and Patricia Aburdene. Megatrends 2000. Jakarta: Binarupa Aksara, 1990.

Namasivayam, K, and Zhao, X., "An investigation of the moderating effects of organizational commitment on the relationship between work-family conflict and job satisfaction among hospitality employees in India", Tourism Management, Volume 28, Number 5 (2006): 1212-23.

Nart, Senem and Ozgur Batur, "The relation between work-family conflict, job stress, and organizational commitment and job performance: a study on Turkish primary teacher", European Journal of Research and Education, Volume 2, Number 2 (2014): 72-81.

Neck, Christopher, Milliman, P, and John F,'Thought self-leadership: Finding spiritual fulfillment in organizational life", Journal of Managerial Psychology, Bradford, Volume 9, Number 6 (1994): 9-16.

Pala, Fikri, Eker Semin, Melee Eker, "The Effects of Demographic Characteristics on Organizational Commitment and Job Satisfaction: An Empirical Study on Turkish Health Care Staff", The Journal of Industrial Relations and Human Resources, Volume 10, Number 2 (2008): 54-75. 
Rego, Arménio and Cunha, Miguel Pina e,"Workplace spirituality and organizational commitment: an empirical study", Journal of Organizational Change Management, Volume 21, Number 1 (2008): 53-75.

Robbins, Stephen P. Organizational Behavior. NJ: Prentice Hall, 2000.

Salami, Samuel O, "Demographics and Psychological Factors Predicting Organizational Commitment among Industrial Workers", Anthropologist, Volume 10, Number 1 (2008): 31-38.

Sanders III, Joseph E. Hopkins, Willie E. and Gary D Geroy, "A Causal Assessment of the Spirituality-Leadership-Commitment Relationship", Journal of Management, Spirituality $\mathcal{E}$ Religion, Volume 2, Number 1 (2005): 39-66.

Silverthorne, Colin P. Organizational Psychology in Cross-Cultural Perspective. San Fransisco: NYU Press, 2005.

Sorizehi, Zakaria, Naser Kamalipur, Keramat Qhalandarzehi, and Abdul Aziz Jamshidzehi," Studying the impact of workplace spirituality on organizational commitment (case study: agricultural jihad organization in Khash City)", International Journal of Academic Research in Business and Social Sciences, Volume 4, Number 6 (2014): 8-19.

Subekti, Mukodas Arif, "Strategi Kemenag dalam Memperteguh Komitmen Menjadikan Kementerian yang Bebas dari Korupsi”, Downloaded October 28, 2016 from:www.odazzander.com.

Torkamani, Z. Najafluye, A. Z Naami, S. E. Sheykhshabani, Hasbemi. K Beshlide, "The effect of spiritual leadership with organizational commitment, productivity, and knowledge performance with mediating spiritual well being and learning organization in employee of bidboland gas company", International Journal of Psychology and Behavioral Research, Volume 4, Number 1 (2015): 133-143.

Usman, Ali and Danish, Rizwan Qaiser,"Leadership spirituality in banking professionals and its impact on organizational commitment", International Journal of Bussines and Management, Volume 5, Number 3 (2010): 185 193.

Vandenberghe, Christian, "Workplace spirituality and organizational commitment; an integrative model", Journal of Management, Spirituality, and Religion, Volume 8, Number 3 (2011): 211-232.

Viet, Vo Van, "Demographic Factors Affecting Organizational Commitment of Lecturers", Journal of Science: Education Research, Volume 31, Number 4 (2015): 16-25. 
IJIMS, Indonesian Journal of Islam and Muslim Societies, Volume 7, Number 2, December 2017: 277-304

Wainaina, Lawrence, Mike Iravo, Anthony Waititu, "Workplace spirituality as a determinant of organizational commitment amongst academic staff in the private and public universities in Kenya”, International Journal of Academic Research in Business and Social Science, Volume 4, Number 12 (2014): 280-293.

Wigglesworth, Cindy, "Spiritual intelligence and why it matters", Downloaded on January 2, 2016, from www.deepchange.com

www.kompas.com, "Tantangan Birokrasi Pemerintahan Jokowi-JK", Retrieved March 13, 2016.

Yucel, Ilhami, Cetin Bektas, "Job Satisfaction, Organizational Commitment and Demographic Characteristics among Teachers in Turkey: Younger is Better?" Procedia Social and Behavioral, Volume 46 (2012) 1598-1608. 